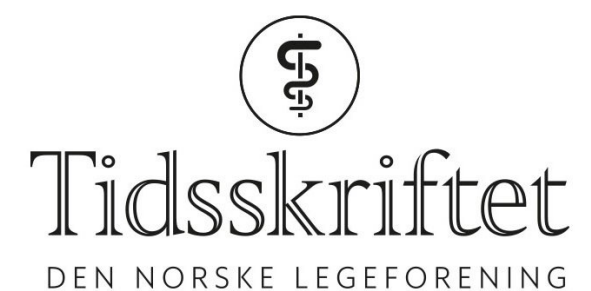

DEN NORSKE LEGEFORENING

\title{
Språkopplæring for leger fra utlandet
}

KOMMENTAR

\section{TONE GREVE GEDDE}

E-post: t.g.gedde@iln.uio.no

Tone Greve Gedde er tidligere universitetslektor.

Ingen oppgitte interessekonflikter.

Takk til Bergljot Holm Årstad for kommentar!

Det er riktig at jeg vurderer språknivået B2 som lavt for personer som skal avlegge eksamen i nasjonale fag, men mine uttalelser gjaldt først og fremst det som kreves for å bestå Fagprøven. Fagprøven gjeninnføres fra høsten 2017 og vil altså koste 49 ooo per forsøk (1). I tillegg kommer kursene i nasjonale fag som også koster tid og penger. Men jo svakere språklig grunnlag kandidatene har, jo større er faren for at de ikke klarer prøvene.

Når det gjelder årsaker til at nivået B2 er for lavt, mener jeg å ha redegjort for dette, om enn kort, under avsnittet «Legespråk er fagspråk». Ett av mine poeng, som også Bergljot Holm Årstad framholder, er at språkkursene som tilbys, er generelle kurs og at det ikke finnes egne kurs for leger. Men leger trenger solide grunnleggende norskkunnskaper, så egne kurs for leger må bygge videre på de allmenne kursene.

Lærebøkene følger Læreplanen for norsk med samfunnsfag og skal bidra til å gjøre studentene kjent med det samfunnet de har kommet inn i og skal arbeide i. Når det brukes litterære tekster, gir det studenten et utvidet bilde av virkeligheten og tilgang til flere måter å bruke språket på. Holm Årstad konstaterer at «Læreboken «Her på berget» (2) inneholder (...) lange og kompliserte setninger ispedd fremmedord.» Det anser jeg som helt nødvendig for at legene skal bli de avanserte språkbrukerne de trenger å være.

Erfaringsmessig opplever mange av de utenlandske legene at dialekter og sidemål er vanskelig, så ideelt sett burde de lære mer om de ulike språklige variantene de vil møte. Det samme gjelder ulike sider ved det norske samfunnet. Jeg er ikke enig i at tekster om barnehager eller andre forhold som er vanlige hos oss, nødvendigvis er diskriminerende eller indoktrinerende. Det som er mest fremmed, er kanskje det vi aller mest trenger å lese om og diskutere.

I mitt innlegg skrev jeg ikke mye om det norske medisinske fagspråket, men dette er et vesentlig element i det utenlandske leger må tilegne seg, så her er Bergljot Holm Årstad og jeg helt enige. Det kurset vi underviste i mange år, hadde da også dette i navnet (3).

Jeg tror ikke norske leger vil ha problemer med å oppnå nivå B2. Jeg tror ikke de ville ha kommet inn på det medisinske studium uten å ha langt mer enn B2. 
LITTERATUR:

1. Universitetet i Oslo. Det medisinske fakultet. Fagprøven for leger utdannet utenfor EU/EØS og Sveits. https://www.med.uio.no/studier/fagproven/ (2.11.2017).

2. Ellingsen E, Mac Donald K. Her på berget. Oslo: Cappelen Damm, 2016.

3. Gedde TG. Kurs i norsk språk og kommunikasjon for utenlandske leger 1983-2014. Michael 2015; 12: $431-47$.

Publisert: 28. november 2017. Tidsskr Nor Legeforen. DOI: 10.4045/tidsskr.17.0961

(C) Tidsskrift for Den norske legeforening 2020. Lastet ned fra tidsskriftet.no 